\title{
HONOURS, AWARDS AND APPOINTMENTS
}

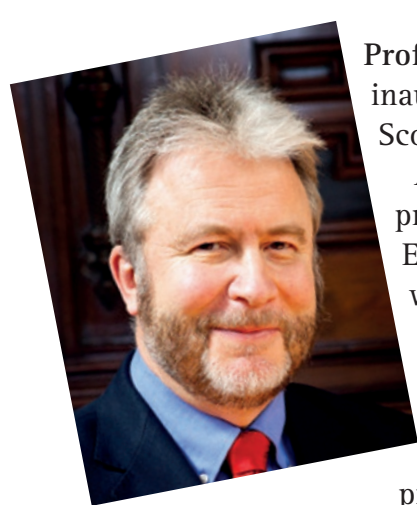

Professor Richard Welbury has won the inaugural Dentist Award at this year's Scottish Health Awards.

At a ceremony hosted by comedian and presenter Fred MacAulay in the Corn Exchange in Edinburgh, Professor Welbury was presented with his award by Scottish Cabinet Secretary for Health, Wellbeing and Sport, Shona Robison.

Professor Welbury has been campaigning for the work of the dental profession to be more integrated into

healthcare, particularly in the field of child protection, for more than 30 years.

Professor Welbury said after the event: 'I am really chuffed. I don't enjoy being in the limelight but anything that raises the value of the dental team in the public eye has to be positive.'

Mandy Payne, previously a specialist in paediatric dentistry, has just won a huge contemporary art prize at the New Light Prize Exhibition.

The winner of the $£ 10,000$ Valeria Sykes Award for Broken Brutalism, Mandy studied for a BA in Fine Art with the University of Nottingham while working at a NHS dentist. Since 2012, she has been a full-time artist. Her work explores Park Hill in Sheffield, a Grade II* listed council estate and one of Britain's

largest examples of Brutalist architecture. Beyond Brutalism depicts the urban flux which the estate currently illustrates, with some parts of it transformed into luxury flats while other areas remain boarded up and derelict. Mandy uses materials integral to the estate itself to produce her work, namely aerosol paints which reference the graffiti on the buildings and concrete.

Laura Gascoigne, art reviewer and judge, said of their decision: 'Given the extraordinarily wide variety and high standard of this year's short-list, choosing a single winner was a difficult decision but, in the end, Mandy Payne's work stood out for the originality of its concept as well as its subtle artistry and technical skill.'

The former Tanzania Health Minister

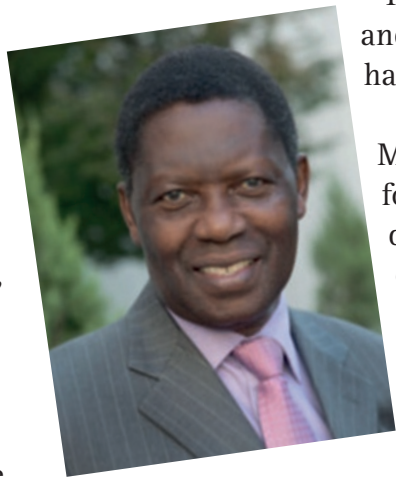
and MP, Professor David Mwakyusa, has joined Bridge2Aid as a Patron.

Professor Mwakyusa served as Minister for Health and Social Welfare for 5 years between 2005 and 2010, during which time he made effective changes in various health policies which saw improvement in many statistics related to human resources for health, malaria, HIV/AIDS, tuberculosis and child health.

He is the author of the Tanzania primary Health Services Programme which is credited for revolutionising health care delivery in Tanzania

\section{DATE FOR THE DIARY}

The British Undergraduate Dental Research Conference will take place on Saturday 27 February, 2016 at the University of Manchester. For further information please contact the Manchester Undergraduate Dental Research Society (MUDRSoc).

\section{IN THIS ISSUE...}

A study led by scientists from King's College London has explored whether the fee status of a UK patient influences clinical decision-making in endodontics. The research has been published on page 541 of this issue.

In a randomised-controlled vignette study using either an NHS-funded or privatelyfunded or undisclosed fee-status patient, the investigators examined the importance dentists placed on the funding status when deciding to offer patients endodontic treatment, as opposed to extracting the tooth. The research team, including Drs Koula Asimakopoulou, Dave Gilbert and Ian Walker from the Dental Institute at
King's College London, were pleased to find that there is no strong evidence to suggest that the fee-status of a patient influences the decision-making in endodontic treatment.

The researchers commented: 'This is only a small scale study using hypothetical scenarios and highly experienced dentists but on the basis of our findings we have no reason to believe that dentists get unduly influenced by the fee-status of their patients before making treatment decisions.'

For more on lead author Dr Asimakopoulou, read her interview in volume 219 issue 3 of the BDJ: http://www.nature. com/bdj/journal/v219/n3/full/ sj.bdj.2015.589.html. 